\title{
Empowering citizens against corruption with civic education
}

\author{
Venny Rika ${ }^{1}$, I Putu Windu Mertha Sujana ${ }^{2}$, I Wayan Landrawan ${ }^{3}$ \\ \{vennyrika11@gmail.com¹, windu.mertha@undiksha.ac.id², wayan.landrawan@undiksha.ac.id ${ }^{3}$ \} \\ Universitas Pendidikan Ganesha, Indonesia ${ }^{1,2,3}$
}

\begin{abstract}
The success of a country can be seen in cooperative relationships with citizens in achieving a common goal. A state must be present as social control for citizens in solving various existing problems. Corruption is one of the biggest problems that must be fought in a country. This can occur due to several factors such as low awareness or knowledge, weak guiding laws, insistence on economic needs, abuse of position or power, and even a culture where corruption is common. Therefore, this study will examine the role of Citizenship Education in empowering citizens to fight corruption in Indonesia. Citizenship Education does not only talk about theory, but rather its implementation to make good citizens synergize in achieving state goals. Empowerment of citizens in corruption Citizenship Education provides the basis for forming wise and courageous citizens to act in eradicating the corruption of the values of Pancasila.
\end{abstract}

Keywords: Corruption; Citizens and Civic Education

\section{Introduction}

Corruption is a serious disease that often occurs in many countries, including Indonesia. The State of Indonesia has now reached 75 years of independence but is still not free from corruption. This seems to have become a culture that cannot be separated from this country which is known as the "sleeping Asian tiger". This disease, which has been mushrooming for a long time, continues to mushroom regardless of circle, age and place, which often occurs without us knowing it. The criminals became more and more joking until the people's screams became less and less audible. The replacement of state leaders who spread sweet promises against corruption eradication is like mere talk that raises public doubts about the government. Kompas.com [1] mentions that there is an infographic on the 7 biggest corruption cases in Indonesia starting from the Jiwasraya case with a loss ofRp.13.7 trillion, the Century Bank case with a loss of Rp. 7 trillion, Pelindo II case with a loss of Rp. 6 trillion, the case of the East Kotawaringin Regent with a loss of Rp. 5.8 trillion, BLBI cases with a loss of Rp. 4.58 trillion, E-KTP case with a loss of Rp. 2.3 trillion and the Hambalang Case with a loss of Rp. 706 billion.

These cases are only a few of which have been revealed not to mention other cases that have not been revealed yet arestillmysteries. Corruption cases that are increasingly published day after day make it furious not to mention the offenders from state officials who make public trust in the state decline. State officials who should be role models for society are now increasingly coloring the rodent drama in this country. Often people are made victims of injustice 
for the sake of bribes of wealth for irresponsible people. The wrong perception is able to provoke people into action. Our culture that often gives envelopes as a form of gratitude to state officials can also be categorized as an act of corruption. Including small things such as not being on time is an act of corruption, of course with differentactions[2].

Empowering citizens in fighting corruption must be encouraged by the state by paying attention to various aspects that are in accordance with the identity of this nation. Indonesia, with all its diversity based on a sense of the same fate, commitment and struggle, should be able to unite the nation to fight this corruption problem. One of the simple things is through Citizenship Education in education[3]. The provision in the form of this theory is very precise according to the basis of our country, namely Pancasila which is from the values of the Indonesian nation itself. Through Citizenship Education, it is hoped that it will be able to form a generation that is wise and has the courage to act in fighting corruption[2]. Not just memorizing the theory of being a citizen to achieve the goals of the state, but also being able to implement it in the real life of society, nation and state.

This study will examine the role of Citizenship Education in empowering citizens to fight corruption in Indonesia. From this research, it is hoped that a calm solution to solving corruption can be obtained from the perspective of civic education. Especially moral education which can shape the anti-corruption character of the younger generation.

\section{Method}

This article is a literature review using a qualitative descriptive method. In terms of the topic, it is a form of social science study related to the empowerment of citizens in criminal acts of corruption that occur in Indonesia through Citizenship Education. Researchers will collect various references that are relevant to the topic raised. Furthermore, the reference sources will be analyzed critically-systematically. The data obtained will be presented descriptively and the symptoms, events and incidents that occur in society with regard to corruption. Descriptive method focuses on actual problems in the field, it aims to find solutions to the problems raised.

The stages of the implementation of this research started from determining the topic of kajia, then conducting a critical analysis of various sources in the mass media, both print and online such as kompas.co.id, vivanews.com, balipost.com and so on. Furthermore, the preliminary data is analyzed with the prevailing laws and regulations such as the anti-corruption law, the State Civil Apparatus Law, the Manpower Law, and so on. These regulations become an ideal model in preventing corruption. In addition, studies were also carried out on regulations concerning the police, prosecutors, and policies in the education sector. The whole study then becomes the basis of analysis to explain the position of citizenship education in creating good citizens, especially against acts of corruption.

\section{Result and Discussion}

\section{Corruptors joke more and more until the people's screams are not heard, why?}

According to the Big Indonesian Dictionary, the word "corruption" means fraud or embezzlement (state or company money) and so on for personal or other people's gain [4]. Corrupt acts always contain elements of "misappropriation" or dishonesty Based on Law Number 28 of 1999 concerning State Diversion that is Clean and Free from Corruption, Collusion and Nepotism [5], it is stated that corruption is a criminal act as referred to in the provisions of the statutory regulations governing corruption [5]. Corruption comes from the Latin coruptio and corruptus which means damage or depravity. In Greek, corruption is an act that is not good, bad, cheating, can be bribed, immoral, deviates from sanctity, violates religious, material, mental and general norms. Corruption is an act against the law to enrich oneself personally or others, 
including: (1) bribery, (2) conflicts of interest, (3) economic exortion, and (4) illegal gratuities [6].

From the understanding that has been stated above, it is clear that corruption is very detrimental both materially and morally. There are many factors that influence someone to commit acts of corruption, both internal and external. Internal factors come from within the desires of the individual itself, such as greediness that always wants more must be obtained not to mention a consumptive lifestyle so that you try to get what you want in any way. Lack of awareness of moral and professional responsibility is also an opening to encourage someone to act corruption. External factors occur as a result of influence from outside the individual itself, such as for the sake of politics to survive and even rise in a position, weak regulatory laws, insufficient economic demands, weak supervision within the organization that triggers fraud to occur.

From the understanding that has been stated above, it is clear that corruption is very detrimental both materially and morally. There are many factors that influence someone to commit acts of corruption, both internal and external. Internal factors come from within the desires of the individual itself, such as greediness that always wants more must be obtained not to mention a consumptive lifestyle so that you try to get what you want in any way. Lack of awareness of moral and professional responsibility is also an opening to encourage someone to act corruption. External factors occur as a result of influence from outside the individual itself, such as for the sake of politics to survive and even rise in a position, weak regulatory laws, insufficient economic demands, weak supervision within the organization that triggers fraud to occur.

Based on the results of research conducted by the World Bank [7], other factors have contributed to the occurrence of corruption, especially in Indonesia, as follows: First, the result of the former colonial government. Even corruption did not only exist in the colonial government, but also continued to develop as an indirect influence by the incitement of the nationalists against the government. Second, the number of civil servants is increasing rapidly as a result of which their salaries are very low. This resulted in the need for additional income and the expansion of bureaucratic power and opportunities coupled with weak control from above and the influence of political parties. Third, customs in the past and still attached to a society, such as family solidarity and the habit of giving gifts to each other are considered causes of corruption, in addition to sudden changes in history. Fourth, phenomenologically, corruption is made, it will be found that the elements that exist in corruption are fraud and theft. If it takes the form of extortion, it means theft and coercion of the victim. If it takes the form of a bribe against an official, it means helping the theft occur. When corruption occurs in the determination of a corruption contract, it is the thef to the decision as well as the money that is the result of the decision. Fifth, the resulting opportunities for corruption and party competition in some countries can also provide the basis for a marked increase in corruption.

In the midst of technological advances accompanied by the increasing necessities of life, everyone is competing to survive the rigors of civilization. The law on corruption isconstantly being revised, the flushing of funds continues to be disbursed, but the corruptors are still hanging around. Every day the corruptors joke around and again the people become victims of the ruthlessness of the state money-trapping actors. Perpetrators are not just ordinary people, even state officials also play in the rodent drama. Legalizing all means for the sake of mere profit, bribing here and there, pulling here and there while the people only accept the remnants which even make their heads shake. This problem cannot be ignored and it is not the responsibility of the government alone, but our collective obligation to continue to uphold justice for the common welfare. 
Reporting from Transparency International, Indonesia shows the results of the Corruption Perceptions Index (CPI) in 2018 where Indonesia is in 89th position with a score of 38 [8]. These results have increased by seven levels compared to 2017 which was in the position96 with a score of 37 . The CPI or CPI itself is calculated methodologically by Transparency International on a scale of $0-100$ with calculations from 180 countries. This shows a slight change in Indonesia, neither for the better nor for the worse in terms of corruption. We must appreciate these changes and become our enthusiasm in fighting corruption in this country. It is a sign that what is damaged can be fixed if we cooperate in preventing, taking action to control something both by the state and citizens.

\section{The state must be present and connected with citizens}

Based on the 1945 Constitution Article 1, paragraph 3, which "Indonesia is a rule of law" [9]. In addition, based on Article 26 of the 1945 Constitution, paragraph 1 "those who become citizens of the Indonesian nation are native Indonesians and people of other nations who are legalized by law as citizens" [10]. So in that case, citizens play a role in influencing what is happening and will happen in their country. Not to mention that Indonesia is a democratic country which is from the people by the people and for the people. So on that basis we should be increasingly united in fighting the ignorance that has been eating away at this nation for a long time. The state must be a social control as well as a role model for citizens in achieving the goals of the state itself. The state must be present and connected to the people, not just listening and responding with the word "patient and waiting" but real action in one goal of achieving a truly independent country.

Quoting the words of the famous French Emperor and General Napoleon Bonaparte [11], "The world suffers a lot. Not because of the violence of bad people but because the silence of good people". That, the world has suffered a lot. Not because of the actions of bad people, but because of good people who were silent. The state must be present in ensuring the security and comfort of its people in their life without fear of being pressured. The state must be aware of and act, one of which is to form an institution or anything else to solve this corruption problem. Quoting from the National Law Development Agency, there are institutions and handling of corruption eradication, such as the division of investigations and investigations into criminal acts of corruption delegated to the Police, the Attorney General's Office and the KPK [12]. Meanwhile, the prosecution for corruption is left to the Attorney General's Office and the KPK [12]. This is of course adjusted to the classification of corruption crimes regulated in Law No. 31 of 1999 in conjunction with Law No. 20 of 2001 [13].

The establishment of the Corruption Eradication Commission, which is stipulated by Law Number 30 of 2002 [14] concerning the Corruption Eradication Commission to overcome, overcome and eradicate corruption, is an independent commission which is expected to become a "weapon" for perpetrators of corruption [15], collusion and nepotism. The objective of forming the commission is to increase the effectiveness and effectiveness of efforts to eradicate corruption [14]. A series of actions to prevent and eradicate criminal acts of corruption through efforts to coordinate, supervise, monitor, investigate, investigate, prosecute, and examine court proceedings, with the participation of the public based on applicable laws and regulations called the eradication of corruption [15]. In its duties, the KPK collaborates with the Corruption Eradication Team (Timtas Tipikor), the State Administrative Wealth Audit Commission (KPKPN), and the National Ombusman Commission. The Corruption Eradication Commission is domiciled in the capital city of the Republic of Indonesia and its working area covers the entire territory of the Republic of Indonesia [16]. 
The success of a country can be measured from its synergistic relationship with its citizens. Instinctively humans are social creatures who need each other. The wall of social inequality should be leveled because it again returns to the basis of the country where they stand. Indonesia with Pancasila as the basis of the state provides the essence of human life to be fair for welfare by thinking wisely while paying attention to every aspect of life. Citizens play an important role in fighting corruption. Through Law No. 31 of 1999 in conjunction with Law No. 20 of 2001 concerning the Eradication of Corruption in Article 41, which basically means that the community has the right and responsibility in efforts to prevent and eradicate corruption in accordance with applicable regulations and others [13]. The participation of the community in efforts to prevent, eradicate and reveal corruption, of course, has received a certain appreciation from the state in accordance with applicable regulations [16]. The legal basis for the public to be able to participate in the prevention and eradication of Corruption Crime has actually been regulated in article 108 paragraph 1 and paragraph 3 of Law Number 8 of 1981 concerning the Criminal Procedure Code (KUHP), namely: (1) Every person who has experienced, seen, witnessed and or been a victim of an incident which constitutes a criminal act has the right to submit a report or complaint to the investigator and / or investigator, either orally or in writing; (2) Every civil servant in carrying out his / her duties who knows about the occurrence of an event which constitutes a criminal act is obliged to immediately report it to the investigator or investigator [17].

The state must design maximally according to the capabilities and needs of the country from various aspects. Considerations in terms of economy, religion, culture, health, technology and of course education can be a way for the state to educate citizens to be careful as a state. With full awareness, citizens are able to carry out what is their obligation to the state not because of demands but with a sense of pride ready to serve the state. This of course does not talk about being ready or not but willing or not to learn because after all the country continues to move and change, it must continue to transform and adapt wisely according to the values of the nation. If the citizens are strong, the state will be very easy to carry out its duties and vice versa. Establishing communication and cooperation through education, implementation and appreciation is an alternative way to create an Indonesia that is free from corruption, of course, with an appropriate evaluation of the values of this nation.

\section{Civic Education as a provision against corruption}

Corruption is clearly very detrimental and contrary to the values of the Indonesian nation. Various ways have been made by the government to eradicate this problem, one of which is through education or what is usually taught in school under the name Citizenship Education. These subjects are not only taught in school but up to the college level with different prospects. Citizenship Education is basically a way to equip students as good citizens to contribute to the country in the future. This compulsory subject contains the essence of every aspect of Indonesian life. Starting from studying the history of the value of the Indonesian nation, the state's goals include the rights and obligations as citizens of the state and others. In addition to this, of course, it is also necessary to instill an anti-corruption attitude in students in every learning process. Attitude is an important componentin developing the culture or character of students in doing good. According to Sax, attitude is "a preference along a dimension of favorableness to unfavorability to a particular group, institution, concept, or object" [18].

Citizenship Education is one of the subjects that must be included in the educational curriculum in all educational units [12]. This is in accordance with Law Number 20 of 2003 Article 37 paragraph 1 concerning the National Education System [19]. The vision of Citizenship Education subjects is the realization of a subject that functions as a means of fostering national 
character and empowering citizens. Meanwhile, the mission of the Citizenship Education subject is to form good citizens, namely citizens who are able to carry out their rights and obligations in state life, based on political awareness, legal awareness and morals . Citizenship Education is one of the fields of study that carries out a national mission to educate the life of the Indonesian nation through the corridor of "value-based education", namely to foster and develop the active thinking abilities and skills of citizens, especially the younger generation in participating and being responsible in the life of the nation [20].

This is again explicitly reinforced in the research conclusion delivered (CCE, 1999) that the content for the new civic education should include key concepts such as democracy, good governance, anti-corruption, the constitutional, national identity, and civic value. The results of this conclusion provide a strengthening of the urgency of the anti-corruption insight as a new paradigm of the content of Civics [6]. The Center for Indonesian Civic Education's recommendation is one of the foundations for the purpose of Citizenship Education at the primary and secondary education levels, namely "Participating actively and responsibly, and acting intelligently in social, national and state activities, as well as anti-corruption" [21].

This form of prevention or prevention in fighting corruption is very effective by equipping citizens through Citizenship Education. Corruption is included in white collar crime, as well as extra ordinary crime. So that this nation needs to formulate a structured, systematic, effective and comprehensive strategy as a preventive effort in eradicating criminal acts of corruption. Education is a conscious, planned effort in shaping Indonesian people who have qualified skills, so that they can become citizens who can be relied on by the state. The nature of Pancasila is an anti-corruption character, because it represents praiseworthy behavior. So it needs to be analyzed and reflected on the role of the scientific existence of Citizenship Education as mandatory learning in an effort to internalize anti- corruption values to students, as potential leaders of the Indonesian nation.

The Financial and Development Supervisory Agency of the Republic of Indonesia identified several causes of corruption, namely: individual aspects of the perpetrators of corruption, organizational aspects, aspects of society where individuals live, and corruption caused by a bad system. The Corruption Eradication Commission explained that there are 9 (nine) anti-corruption values which are the basis of morality in staying away from corruptive behavior. This value needs to be socialized and even internalized to the Indonesian people, especially the younger generation. The 9 (nine) values are: 1) core, including honesty, discipline, and responsibility, 2) attitude, including fairness, courage and care, and 3) work ethic, including hard, simple, and independently. The habituation of anti-corruption values is a preventive effort to eradicate corruption crimes. This process which is covered in Citizenship Education is not only theoretical for students. But in the implementation in life that also includes teachers, parents, society, government and others, they must be role models and remind each other.

Based on Regulation of the Minister of National Education No. 22 of 2006 shows the importance of Citizenship Education at the primary and secondary education levels as a vehicle for instilling anti- corruption attitudes and behaviors that are always inherent in the lives of students today and in the future [22]. In an effort to internalize anti-corruption values through Citizenship Education for students, it is certainly more effective if it is implemented with a strategy of analyzing corruption cases. This learning method is basically a form of contextual learning. The existence of Anti-Corruption Education contained in Citizenship Education learning is expected to be able to provide initial provisions regarding knowledge, understanding, and the consequences of corruption, anti-corruption attitudes and behaviors that are always constructed in students as citizens who have Pancasila morality and are responsible for the state. 


\section{Conclusion}

The state must be smart in empowering its citizens in joint efforts to achieve the goals of the country. Every person who is part of Indonesia is obliged to comply with the applicable law in fulfilling their rights and obligations towards the state. State officials are representativesof the people who are elected to carry out the mandate of the state not to be ridden by other interests. Those who used to come from the people should consciously understand what their country needs and maximize their ability to develop the country. Every problem that occurs must be resolved jointly, there is no way to pass responsibility on to the government because they also exist because the people also vote. It must be recognized together that the problem of corruption is very detrimental and must be fought together. One of the prevention efforts through education is Citizenship Education or Civic Education. The state must be present and connected with citizens to create a state free from corruption together. The state of Indonesia is a rule of law, with the implementation of democratic governance in accordance with the values of Pancasila, which has become our solid basis for resolving this corruption problem. When the criminals are joking until people's voices are not heard, then it is appropriate to intensify education on the prevention, eradication and prosecution of corruption in various aspects of society with every available media adjusted to the needs and abilities. Citizenship education is not only memorized theoretically but in its form of implementation in life consciously understanding its role as a good citizen in achieving the goals of the Indonesian state [23].

\section{References}

[1] A. B. Tamtomo, "Infografik: 7 Kasus Korupsi dengan Kerugian Terbesar di Indonesia," Kompas.com, 2020.

[2] S. Asyafiq, "Peran Pendidikan Kewarganegaraan Dalam Membangun Warga Negara Global," Citizsh. J. Pancasila dan Kewarganegaraan, vol. 6, no. 1, hal. 41, Mei 2018, doi: 10.25273/citizenship.v6i1.1880.

[3] R. W. Utami, "Pengembangan Civic Culture Melalui Pendidikan Formal dan Budaya Lokal Masyarakat Suku Nuaulu," Universitas Pendidikan Indonesia, 2015.

[4] Anti Corruption Clearing House, "Modul materi tindak pidana korupsi," hal. 1-80, 2020.

[5] UU RI, "Undang-Undang Nomor 28 Tahun 1999 tentang Penyelewengan Negara yang Bersih dan Bebas dari Korupsi, Kolusi dan Nepotisme." 1999.

[6] H. dan E. D. A.R, "Pendidikan Antikorupsi dalam Pembelajaran PKn Sebagai Penguat Karakter Bangsa," J. Pendidik. dan Pembelajaran, vol. 19, hal. 157-171, 2012.

[7] A. ; E. M. H. E. Y. Supratman, "Analisis Hukum Dalam Pemberantasan Tindak Pidana Korupsi Dalam Perspektif Psikologi Kriminal," USU Law Jpurnal, vol. 5, no. 1, hal. 1-8, 2017.

[8] A. P. Taher, "Indeks Persepsi Korupsi 2018: Indonesia Peringkat ke-89 Dunia," tirto.id, 2019. .

[9] UUD RI, "Undang-Undang Dasar 1945 Pasal 1 ayat 3." 1945.

[10] UUD RI, "Undang-Undang Dasar 1945 Pasal 26 ayat 1." 1945.

[11] A. Ardhyanasari, "Masyarakat Melawan Tindak Pidana Korupsi," Anti Coruption Clearing House, 2017.

[12] R. Saphely, "Keberadaan Komisi Pemberantasan Korupsi dalam Sistem Ketatanegaraan dan Implikasinya terhadap Kewenangan Kejaksaan dan Kepolisian Republik Indonesia,” Syiar Huk., 2017.

[13] UU RI, "Undang-undang No. 31 Tahun 1999 jo Undang-Undang No. 20 Tahun 2001 tentang Pemberantasan Tindak Pidana." hal. 2001.

[14] UU RI, "Undang-Undang Nomor 30 Tahun 2002 tentang Komisi Pemberantasan Tindak Pidana Korupsi Pasal 19 ayat 1," Website KPK RI. hal. 1-40, 2002.

[15] N. Mohede, “Tugas Dan Peranan Komisi Pemberantasan Korupsi Di Indonesia,” J. Huk. Unsrat, vol. xx, no. 1, hal. 67-80, 2012. 
[16] I. M. W. Putra, I. G. A. A. D. Widhiyaastuti, dan I. P. R. A. Putra, "Peran serta masyarak at dalam penceg ahan tindak pidana $\mathrm{k}$ orups i peng elo laan keuang an dana desa, studi di desa cau belayu, kecamatan marga, k abupaten tabanan, propinsi bali I Made Walesa Put ra I Gusti Agung Ayu Di ke Widhiyaastuti I Putu Rasma," vol. 1, hal. 1-16, 2018.

[17] KUHP RI, "Undang-Undang Nomor 8 Tahun 1981 tentang KUHP Pasal 108 ayat 1 dan ayat 3." 1981.

[18] Sutrisno, "Implementasi pendidikan antikorupsi pada mata pelajaran PPKn berbasis project citizen di Sekolah Menengah Atas," J. Civ., vol. 14, hal. 166-175, 2017.

[19] UU RI, "Undang-Undang Nomor 20 Tahun 2003 Pasal 37 ayat 1 tentang Sistem Pendidikan Nasional." 2003

[20] P. Dianti, "Integrasi Pendidikan Karakter Dalam Pembelajaran Pendidikan Kewarganegaraan Untuk Mengembangkan Karakter Siswa," J. Pendidik. Ilmu Sos., vol. 23, no. 1, hal. 58-68, 2016, doi: 10.17509/jpis.v23i1.2062.

[21] M. Murdiono, "Pendidikan Anti Korupsi Terintegrasi dalam Pembelajaran PKn untuk Menanamkan Karakter Kejujuran di SMP,” J. Ilmu-ilmu Sos., vol. 15, hal. 167-183, 2016.

[22] Menteri Pendidikan RI, "Peraturan Menteri Pendidikan Nasional No. 22 Tahun 2006 tentang Standar Isi." 2006.

[23] F. S. Sofyan dan D. Sundawa, "Hubungan Mata Kuliah Pendidikan Kewarganegaraan Dengan Peningkatan Wawasan Kebangsaan Dan Semangat Nasionalisme Mahasiswa," J. Pendidik. Ilmu Sos., vol. 24, no. 2, hal. 185, 2016, doi: 10.17509/jpis.v24i2.1455. 